Al-Tarbawi Al-Haditsah: Jurnal Pendidikan Islam

Vol. 3, No. 2, Desember 2018

\title{
RELEVANSI TRIPUSAT PENDIDIKAN KI HAJAR DEWANTARA DENGAN NILAI-NILAI PENDIDIKAN KARAKTER DALAM SURAT LUQMAN: 12-19
}

\author{
Fithria Rif'atul Azizah \\ Program Studi Pendidikan Islam Pascasarjana \\ UIN Sunan Kalijaga Yogyakarta, Indonesia \\ Email: Fithriaazizah4@gmail.com
}

\begin{abstract}
Abstrak
Karakter bangsa merupakan unsur penting yang harus dikembangkan dalam pendidikan dan berlangsung sepanjang hayat (long life education). Ki Hajar Dewantara yang merupakan salah satu tokoh pendidikan Indonesia memandang bahwa tumbuh kembang seorang anak harus mencakup tiga unsur pendidikan yang disebut dengan tripusat. Sementara itu terlebih dahulu di dalam Al-Qur'an surah Luqman ayat 12-19 juga dijelaskan nilainilai pendidikan karakter sesuai kisah luqman hakim, tentang pendidikan akidah, syaria'ah dan akhlak.

Tujuan dari kajian ini yaitu untuk menemukan titik temu antara pemikiran Ki Hajar Dewantara dengan Surat Lukman ayat 12-19. Penelitian ini menggunakan pendekatan kualitatif, dengan jenis penelitian deskriptif berupa penelitian pustaka (Library Research). Dan metode analisis yang digunakan yaitu metode analisis teks dan bahasa berupa content analysis (analisis isi). Disinilah dilakukan analisis terhadap isi dari gagasan Tri Pusat Pendidikan Ki Hajar Dewantara dan Q.S Lukman ayat 12-19.
\end{abstract}

Kata Kunci: Pendidikan Karakter, Tri Pusat Pendidikan, Kisah Lukman Hakim, Ki Hajar Dewantara
Abstrct
The character of the nation is an important element to be developed in education and long life educations. Ki Hajar Dewantara, who is one of Indonesia's educational leaders who thinks that a child's growth should include three elements of education called education trip center Meanwhile, 


\section{Al-Tarbawi Al-Haditsah: Jurnal Pendidikan Islam}

Vol. 3, No. 2, Desember 2018

firstly in Al-Qur'an sura Luqman: 12-19 also have first described the values of character education according to the story of the luqman hakim, about the education of aqidah, sharia'ah and akhlak.

The purpose of this study is to find the intersection between the thought of Ki Hajar Dewantara with Q.S Luqman: 12-19. This study uses a qualitative approach, with the type of research used is descriptive research in the form of library research. And the method of analysis used is the method of text analysis and language in the form of content analysis. Here is an analysis of the content of the idea of Tri Ki Hajar Dewantara Education Center and Q.S Lukman verses 12-19.

Keyword : Character Education, Tri Education Center, Kisah Lukman Hakim, Ki Hajar Dewantara

\section{A. Pendahuluan}

Pendidikan tidak pernah selesai dan tidak akan pernah selesai dibicarakan. Melalui pendidikan bukan hanya aspek kognitif dan psikomotorik saja yang dicapai dan dikembangkan melainkan perubahan yang positif dari ranah afektif. Tafsir mengungkapkan dalam bukunya bahwa pendidikan kita masih menghasilkan lulusan yang suka menang sendiri dan memaksakan kehendak, suka narkoba dan tawuran, suka curang dan tidak punya kepekaan sosial, termasuk juga koruptor, sehingga semua ini adalah orang yang gagal menjadi manusia sekalipun seorang pejabat. ${ }^{1}$

Di Indonesia sendiri pendidikan karakter sudah di canangkan oleh mantan presiden kita Susilo Bambang Yudhoyono (SBY) sejak tanggal 2 Mei 2010 saat mempertingati hari kemerdekaan Indonesia. Pendidikan karakter saat itu menjadi isu yang hangat, sehingga pemerintah memiliki tekad untuk menjadikan pengembangan karakter dan budaya bangsa sebagai bagian yang tak terpisahkan dari sistem

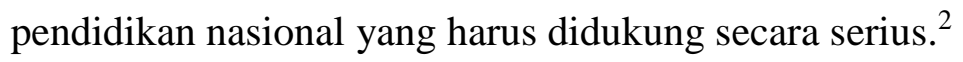

${ }^{1}$ Ahmad Tafsir, Ilmu Pendidikan Islam (Bandung:Remaja Rosdakarya, 2013), 14.

${ }^{2}$ Ahmad Tafsir, Ilmu Pendidikan Islam.... 232 


\section{Al-Tarbawi Al-Haditsah: Jurnal Pendidikan Islam}

Vol. 3, No. 2, Desember 2018

Kemudian pencanangan pendidikan karakter terealisasikan dalam kurikulum 2013 oleh Kementrian Pendidikan Nasional dan Kebudayaan Republik Indonesia. Di dalam kurikulum tersebut terdapat beberapa ranah yang harus terpenuhi yang tercantum dalam KI (Kompetensi Inti), diantaranya KI-1 (Spiritual), KI-2 (attitude), KI-3 (Knowledge), dan KI-4 (Skill). Dan diantara satu kompetensi inti dengan yang lainnya harus saling berkesinambungan. Didalam kurikulum 2013 ini pun pendidikan Agama merupakan suatu mata pelajaran yang dijadikan pilar utama dalam proses implementasinya, yang akan membentuk pendidikan karakter itu sendiri.

Ki Hajar Dewantara juga menegaskan bahwa pendidikan itu suatu tuntunan dalam hidup tumbuhnya anak-anak. Ini dapat diartikan bahwa hidup tumbuhnya anakanak itu terletak di luar kecakapan atau kehendak para pendidik. Anak itu sebagai makhluk, sebagai manusia, sebagai benda hidup dan tumbuh menurut kodratnya sendiri. Menurut Haryanto dalam jurnalnya KI Hajar Dewantara ingin menempatkan anak didik sebagi pusat pendidikan, memandang pendidikan sebagai suatu proses yang dengan demikian bersifat dinamis, serta mengutamakan keseimbangan antara cipta, rasa, dan karsa dalam diri anak. ${ }^{3}$

Dengan demikian, pendidikan yang dimaksud oleh Ki Hajar Dewantara memperhatikan keseimbangan cipta, rasa dan karsa, tidak hanya sekedar proses alih ilmu pengetahuan saja atau transfer of knowladge, tetapi sekaligus pendidikan juga sebagai proses transformasi nilai (transformation of value). Dengan kata lain, pendidikan adalah proses pembentukan karakter manusia agar menjadi sebenarbenarnya manusia. Mengenai pendidikan karakter itu sendiri Ki Hajar Dewantara memandang bahwa dalam tumbuh kembang seorang anak, harus adanya tiga pusat pendidikan yang memiliki peran besar. Semua itu disebut "Tri Pusat Pendidikan".

Berdasarkan pentingnya pendidikan karakter menurut Ki Hajar Dewantara dan Al-Qur'an Surat Lukman ayat 12-19. Artikel ini akan mengkaji tentang relevansi Tri Pusat Pendidikan Ki Hajar Dewantara dengan nila-nila pendidikan karakter yang terdapat dalam surat Luqman ayat 12-19, yang bertujuan untuk menemukan titik temu antara pemikiran Ki Hajar Dewantara dengan Surat Lukman ayat 12-19. Mengetahui

${ }^{3}$ Haryanto. "Pendidikan Karakter Menurut Ki Hajar Dewantara." Jurnal Cakrawala Pendidikan Universitas Garut, th XXX, Spesial Dies Natalis UNY (2011), 19. 


\section{Al-Tarbawi Al-Haditsah: Jurnal Pendidikan Islam}

Vol. 3, No. 2, Desember 2018

apakah Ki Hajar Dewantara membuat gagasan tersebut berlandaskan Surat Lukman ayat 12-19 atau pun tidak. Serta mengetahui kesamaan dan perbedaan dari gagasan Tri Pusat Pendidikan Ki Hajar Dewantara dengan Q.S. Lukman ayat 12-19.

\section{B. Landasan Teori}

1. Konsepsi tentang "Tripusat Pendidikan" menurut Ki Hajar Dewantara, yaitu merupakan suatu upaya pendidikan nasional yang meliputi pendidikan di tiga lingkungan hidup. Pertama lingkungan keluarga, kedua lingkungan perguruan atau sekolah, ketiga lingkungan masyarakat.

2. Ki Hajar Dewantara telah jauh berpikir dalam masalah pendidikan karakter. Menurutnya mengasah kecerdasan budi sungguh baik karena dapat membangun budi pekerti yang baik dan kokoh, hingga dapat mewujudkan kepribadian dan karakter. Selanjutnya Ki Hajar Dewantara mengatakan yang dinamakan budi pekerti atau watak atau dalam bahasa asing disebut dengan karakter yaitu bulatnya jiwa manusia sebagai jiwa yang berasa hukum kebatinan. ${ }^{4}$

Karakter berasal dari bahasa latin "Kharakter", "kharassein”, "kharax”, dalam bahasa Inggris yaitu character dan dalam bahasa indonesia disebut "karakter". Dalam bahasa yunani character dari charessein yang berarti membuat tajam, membuat dalam. Sedangka dalam kamus Poerwadarminta, karakter diartikan sebagai tabiat, watak, sifat-sifat kejiwaan, akhlak atau budi pekerti yang membedakan seseorang dengan yang lain. Nama dari jumlah seluruh ciri pribadi yang meliputi hal-hal seperti perilaku, kebiasaan, kesukaan, ketidaksukaan, kemapuan, kecenderungan, potensi, nilai-nilai, dan pola-pola pemikiran. ${ }^{5}$

3. QS Lukman 12-19

\section{Metode Penelitian}

Penelitian ini menggunakan pendekatan kualitatif, dimana pendekatan kualitatif untuk mengetahui atau menggambarkan kenyataan dari fenomena yang diteliti sehingga memudahkan untuk mendapatkan data yang objektif dalam rangka

${ }^{4}$ Ki Hajar Dewantara. Ki Hajar Dewantara dalam Majelis Luhur Persatuan Taman Siswa. 1997, h.

${ }^{5}$ Hida Ainisyifa. “Pendidikan Karakter Perspektif Pendidikan Islam.” Jurnal Pendidikan UNIGA, no.1, vol.8 (April 2014): 15. 


\section{Al-Tarbawi Al-Haditsah: Jurnal Pendidikan Islam}

Vol. 3, No. 2, Desember 2018

mengetahui dan memahami Relevansi gagasan Tri Pusat Pendidikan KI Hajar Dewantara dengan nilai-nilai pendidikan karakter yang terdapat dalam Q.S Lukman ayat $12-19$.

Jenis penelitian yang digunakan dalam penelitian ini adalah penelitian deskriptif berupa penelitian pustaka (Library Research). Hal ini bermaksud untuk meneliti relevansi Tri Pusat Pendidikan Ki Hajar Dewantara dengan nilai-nilai pendidikan karakter dalam Q.S Lukman ayat 12-19 secara mendalam. Penelitian pustaka yang dikaji adalah buku, jurnalm artikel dan segala sesuatu yang berhubungan dengan gagasan Tri Pusat Pendidikan Ki Hajar Dewantara dan nilai-nilai pendidikan karakter Q.S Lukman ayat 12-19. Dan metode analisis yang digunakan yaitu metode analisis teks dan bahasa berupa content analysis (analisis isi). Disinilah dilakukan analisis terhadap isi dari gagasan Tri Pusat Pendidikan Ki Hajar Dewantara dan Q.S Lukman ayat 12-19.

\section{Pendidikan Karakter Melalui Tri Pusat Pendidikan}

Menurut Imam Ghazali yang dikutip oleh karakter adalah suatu sifat yang tertanam dalam jiwa yang menimbulkan perbuatan-perbuatan dengan mudah tanpa melakukan pertimbangan pikiran. ${ }^{6}$ Karakter adalah sifat kejiwaan, akhlak atau budi pekerti yang menjadi ciri khas seseorang atau sekelompok orang. Membentuk karakter tidak semudah memberi nasihat dan juga tidak semudah memberi instruksi tetapi memerlukan kesabaran, pembiasaan dan pengulangan.

Disisi lain Russel Williams mengilustrasikan bahwa karakter ibarat otot, dimana otot-otot karakter akan menjadi lembek apabila tidak pernah dilatih, dan akan kuat dan kokoh jika sering digunakan. Seperti halnya binaragawan (body budler) yang terus menerus berlatih untuk membentuk ototnya, otot-otot karakter juga akan terbentuk dengan praktik latihan yang akhirnya akan menjadi kebiasaan (habit).

Winnie memahami bahwa istilah karakter memiliki dua pengertian. Pertama, Ia menunjukkan bagaimana seseorang bertingkah laku. Menurutnya, apabila seseorang berperilaku tidak jujur, kejam, atau rakus, hal tersebut merupakan manifestasi dari

${ }^{6}$ Muh Arif. “Nilai-Nilai Pendidikan Karakter dalam Al-Qur'an (Studi Q.S Luqman: 12-19). ” Jurnal Irfani, no.1, vol.11 (2015): 14-15. 


\section{Al-Tarbawi Al-Haditsah: Jurnal Pendidikan Islam}

Vol. 3, No. 2, Desember 2018

perilaku yang buruk. Sebaliknya, jika seseorang berperilaku jujur, suka menolong, hal tersebut merupakan manifestasi dari karekter yang baik/mulia. Kedua, istilah karakter erat kaitannya dengen personality dan seseorang baru dapat disebut orang yang berkarakter (a person of character) apabila tingkah lakunya sesuai kaidah moral. ${ }^{7}$

Majid dan Andayani menjelaskan bahwa secara alami sejak lahir sampai berusia tiga tahun, atau mungkin sekitar lima tahun. Kemampuan menalar seorang anak belum tumbuh sehingga pikiran bawah sadar (subconscious mind) masih terbuka dan menerima apa saja informasi dan stimulus yang di masukkan kedalamnya tanpa ada penyeleksian, mulai dari orang tua dan lingkungan keluarga. Dari mereka itulah, pondasi awal terbentuknya karakter sudah terbangun. ${ }^{8}$

Menurut Honrnby dan Parnwell karakter adalah kualitas mental atau moral, kekuatan moral, nama atau reputasi. ${ }^{9}$ Dan Kertajaya mendefinisikan karakter adalah ciri khas yang dimiliki oleh suatu benda atau individu. Ciri khas tersebut merupakan mesin pendorong bagaimana seorang bertindak, bersikap, berujar, dan merespons sesuatu. ${ }^{10}$

Sedangka pendidikan karakter itu sendiri menurut Aneess dalam bukunya yaitu pendidikan untuk membentuk kepribadian seseorang melalui pendidikan budi pekerti, yang hasilnya terlihat dalam tindakan nyata seseorang, yaitu tingkah laku yang baik dan jujur, bertanggung jawab, menghormati hak orang lain, kerja keras, dan lain sebagainya. Hal ini pula dapat dikaitkan dengan takdib, yaitu pengenalan dan afirmasi atau aktualisasi hasil pengenalan. ${ }^{11}$

Lingkungan keluarga merupakan pusat pendidikan yang berada di urutan pertama dan terpenting. Karena sejak dahulu kala hingga sekarang, lingkungan keluarga selalu mempengaruhi pertumbuha budi pekerti dan karakter setiap orang.

Setelah lingkungan keluarga posisi kedua yaitu lingkungan perguruan atau sekolah. Lingkungan sekolah merupakan suatu lingkungan yang bertanggung jawab

\footnotetext{
${ }^{7}$ F.Muin. Pendidikan Karakter Konstruksi Teoritik dan Praktik. Yogyakarta: Ar-Ruzz, 2011, h. 160.

${ }^{8}$ Abdul Majid, Dian Andayani. Pendidikan Karakter Perspektif Islam. Bandung: PT. Remaja Rosdakarya, 2012, h. 18.

${ }^{9}$ Ibid 49

${ }^{10}$ Ibid 3

${ }^{11}$ B.Q.Anees. Pendidikan Karakter Berbasis Al-Qur'an. Bandung: Simbiosa Rakatama, 2010, h. 99.
} 


\section{Al-Tarbawi Al-Haditsah: Jurnal Pendidikan Islam}

Vol. 3, No. 2, Desember 2018

untuk mengusahakan kecerdasan pikiran (perkembangan intelektual) serta pemberian ilmu pengetahuan (balai wiyata).

Lingkungan selanjutnya yang tidak kalah berpengaruh yaitu lingkungan masyarakat. Dimana lingkungan ini ranah seseorang untuk beraktivitas dan mengaktualisasikan dan mengembangka potensi-potensi yang mereka miliki.

Menurut Gunawan dalam bukunya terdapat beberapa keterangan Ki Hajar Dewantara yang cukup menarik perhatian tenang Tripusat Pendidikan, yaitu :

1. Keinsyafan Ki Hajar Dewantara bahwa tujuan pendidikan tidak mungkin tercapai melalui satu jalur saja.

2. Ketiga pusat pendidikan itu harus berhubungan seakrab-akrabnya serta harmonis.

3. Bahwa alam keluarga tetap merupakan pusat pendidikan yang terpenting dan memberikan pendidikan budi pekerti, agam, dan laku sosial.

4. Bahwa perguruan sebagai balai wiyata yang memberikan ilmu pengetahuan dan pendidikan ketrampilan.

5. Bahwa alam pemuda (yang sekarang diperluas menjadi lingkungan/alam kemasyarakatan) sebagai tempat sang anak berlatih membentuk watak atau karakter dan kepribadiannya.

6. Dasar pemikiran Ki Hajar Dewantara ialah usaha untuk menghidupkan, menambah dan memberikan perasaan kesosialan sang anak. ${ }^{12}$

Berdasarkan pemaparan diatas, kita dapat mengetahui bahwa Ki Hajar Dewantara tidak memandang perguruan atau sekolah sebagai lembaga satu-satunya yang memiliki orientasi mutlak dalam proses pembentukan karakter anak. Justru dia memandang bahwa pendidikan sebagi suatu proses yang harus melibatkan unsur-unsur lain dari luar sekolah. Tiap-tiap pusat tersebut harus mengetahui kewajibannya masing-masing, atau kewajibannya sendiri-sendiri, dan mengakui hak pusat-pusat lainnya, yaitu lingkungan/alam keluarga, untuk mendidik budi pekerti dan laku sosial. Lingkungan/alam sekolah sebagai balai wiyata bertugas mencerdaskan cipta, rasa dan

\footnotetext{
${ }^{12} \mathrm{Ki}$ Gunawan. Aktualisasi Konsep Pendidikan Ki Hajar Dewantara dalam Sistem Pendidikan Nasional Indonesia di Gerbang XXI dalam Ki Hajar Dewantara di Dalam Pandangan Para Cantrik dan Mantriknya. Yogyakarta: MLPTS, 1989, h. 36.
} 


\section{Al-Tarbawi Al-Haditsah: Jurnal Pendidikan Islam}

Vol. 3, No. 2, Desember 2018

karsa secara seimbang. Dan lingkungan masyarakat/alam pemuda untuk melakukan penguasaan diri dalam pembentukan watak atau karakter.

Ketiga pusat pendidikan tersebut sangat erat kaitannya satu dengan yang lainnya, sehingga tidak dapat di pisahkan, dan memerlukan kerjasama yang sebaikbaknya. Untuk memperoleh hasil pendidikan maksimal seperti yang dicita-citakan. Hubungan sekolah dengan rumah bagi peserta didik sangatlah erat, sehingga berlangsungnya pendidikan terhadap anak selalu dapat diikuti serta diamati, agar dapat berjalan sesuai dengan tujuan yang dikehendai. Guru atau pamong sebagai pimpinan harus bertinda tut wuri handayani, ing madya mangun karsa, dan ing ngarsa sung tuladha yaitu mengikuti dari belakang dan memberi pengaruh, berada di tengah untuk memberi semangat, dan berada didepan sebagai teman.

Sistem pendidikan yang dikemukakan oleh Ki Hajar Dewantara merupakan warisan luhur yang patut di implementasikan dalam perwujudan masyarakat yang berkarakter. Jika para pendidik sadar bahwa keteadanan adalah upaya nyata dalam membentuk anak bangsa yang berkarakter, semua tentu akan terus mengedepankan keteladanan dalam segala perkataan dan perbuatan. Dengan keteladanan, karakter religius, jujur, toleran, disiplin, kerja keras, cinta damai, peduli sosial, dan karakter lain tentu akan berkembang dengan baik.

Begitu pula jika kita sadar bahwa berkembangnya karekter peserta didik memerlukan dorongan dan arahan pendidik, sebagai pendidik tentu kita akan terus berupaya menjadi motivator yang baik. Dengan dorongan dan arahan pendidik, karakter kreatif, mandiri, menghargai prestasi, dan pemberani peserta didik akan terbentuk dengan baik.

Sementara itu, ada kalanya pendidik perlu memberikan keleluasaan dan atau kebebasan kepada peserta didik untuk menentuka pilihannya sendiri. Hal demikian di mungkinkan dapat mengembagkan karakter demokratis dan bertanggung jawab.

\section{E. Nilai-Nilai Pendidikan Karakter dalam Al-Qur'an Surat Luqman Ayat 12-17}

\section{a) Asbab An-Nuzul Surat Luqman}

Nama Luqman sendiri disebut dalam Al-Qur'an hanya dua kali yaitu d Juz 21 dan menjadi nama surat ke 31. Surat Luqman terdiri dari 34 ayat, dan 


\section{Al-Tarbawi Al-Haditsah: Jurnal Pendidikan Islam}

Vol. 3, No. 2, Desember 2018

tergolong surat makkiyah, kecuali ayat 28, 29, dan 30 yang termasuk dalam surat madaniyyah. ${ }^{13}$

Namun ada juga ulama yang mengecualikan tiga yat yaitu ayat 27-29, atau dua ayat yaitu 27-28 dengan alasan bahwa ayat-ayat ini turun berdasarkan diskusi dengan orang-orang yahudi yang ketika itu banyak bermukim di Madinah. Namun sanad pendapat ini lemah.

Di namakan surat Luqman karena di dalamnya terdapat kisah Luqman, yang nama lengkapnya adalah Luqman bin Ba'ura, salah seorang putra Nabi Ayyub dan termasuk dari suku Naubah dan merupakan bagian dari masyarakat Ailah yakni sebuah kota yang berada di sekitar laut Qulzum. Ia hidup pada masa Nabi Dawud dengan julukan al-Haim (yang Bijak). ${ }^{14}$

Sedangkan menurut Thabathaba'I dan Sayyid Quthub, tema utama pada surat ini adalah ajakan kepada ajaran tauhid dan kepercayaan akan keniscayataan kiamat serta pelaksanaan prindip-prinsip dasar agama. Dan Al-Biqai' berpendapat bahwa tujuan utama surat ini adalah membuktikan betapa kitab al-Qur'an mengandung hikma yang sangat dalam yang mengantarkan kepada kesimpulan bahwa yag menurunkanya adalah Dia yang Maha Bijaksana dalam firman-firman dan perbuatan-perbuatannya, dan yang Maha memberi petunjuk bagi orang-orang yang bertakwa.

Menurut ulama Makkah dan Madinah surat ini terdiri dari 33 ayat sedangkan menurut ulama Syam (Lufah dan Bashrah) surat ini memiliki 34 ayat. Perbedaan ini sebagaimana kita ketahui hanyalah perbedaan cara menghitung saja dan buka berarti ada ayat yang tidak diakui ole yang menilai 33 ayat. ${ }^{15}$

Adapun secara garis besar isi surat Luqman memiliki pokok-pokok sebagai berikut:

a) Keimanan

Al-Qur'an merupakan petunjuk dan rahmat yang dirahasiakan benarbenar oleh orang-orang mukmin. Keadaan di langit dan di bumi serta

\footnotetext{
${ }^{13}$ Ahmad Musthafa Al-Maraghi. Tafsir Al-Maraghi Juz 19. Beirut: Dar Ihya al Turasi, 1991, h. 71.

${ }^{14}$ Zuhaili, dan Nuwaja. Tafsir Ayat-Ayat Pendidikan. Bandung: MARJA, 2002, h. 154.

${ }^{15}$ Muhammad Quraish Syihab. Menyingkap Tabir Ilahi; Asma Al-Husna dalam Perspektif alQur'an. Jakarta: Lentera Hati, 1998, h. 108.
} 


\section{Al-Tarbawi Al-Haditsah: Jurnal Pendidikan Islam}

Vol. 3, No. 2, Desember 2018

keajaiban-keajaiban yang terdapat pada keduanya merupakan bukti atas keEsaan dan kekuasaan Allah. Manusia tiada akan selamat kecuali dengan taat kepada perintah-perintah Allah dan berbuat amal-amal yang shaleh.

b) Hukum-Hukum

Keajaiban patuh dan berbakti kepada kedua orangtua selama tidak bertentangan dengan perintah-perintah Allah, perintah supaya memperhatikan alam dan keajaiban untuk memperkuat keimanan dan kepercayaan akan keEsaan Tuhan, perintah supaya memperhatikan alam dan keajaiban untuk memperkuat keimanan dan kepercayaan akan ke-Esaan Tuhan, perintah supaya selalu bertaqwa dan takut akan pembalasan Tuhan pada hari kiamat di waktu seorang tidak dapat di tolong, baik oleh anak atau ayah ibunya sekalipun.

c) Kisah-Kisah

Kisah tentang Luqman yaitu tentang ilmu dan hikmah yang telah di dapatkan oleh Luqman tentag guru dan orang tua yang bijaksana untuk anakanaknya.

Selain itu terdapat juga pelajaran yang lainnya seperti orang-orang yang sesat dari jalan Allah SWT dan selalu memperolok-olokkan ayat-ayat Allah, Celaan orang-orang musyrik karena tidak menghiraukan seruan untuk memperhatikan alam dan tidak menyembah penciptanya, menghibur hati Rasulullah SAW terhadap keingkaran orang-orang musyrik karena hal ini bukanlah merupakan kelalaian, nikmat dan karunia yang tidak dapat terhitung.

Ahmad Mustafa al-Maraghi menjelaskan bahwa sebab turunnya surat Luqman ialah ada orang Quraisy datang kepada Rasulullah, yang meinta agar dijelaskan kepadanya berkaitan dengan kisah Luqman al-Hakim dan anaknya tentang berbakti kepada kedua orang tuanya, maka turunlah surat Luqman. ${ }^{16}$

Sedangkan para mufasirin berpendapat bahwa surat Luqman ayat 14-15 diturunkan berkaitan dengan Sa'ad bin Abi Waqas ketika masuk Islam. Adapun nama ibunya yakni Hamnah bin Abi Sufyan bin Umayyah. 
Al-Tarbawi Al-Haditsah: Jurnal Pendidikan Islam

Vol. 3, No. 2, Desember 2018

\section{b) Biografi Lukman al-Hakim Menurut Beberapa Ulama}

1. Ahmad Musthafa al-Maraghi

Lukman al-Hakim adalah seorang tukang kayu, kulitnya hitam dan masuk penduduk Mesir yang hidup serba sederhana. Namun demikian, Allah SWT telah memberikannya hikmah dan menganugerahkan kenabian kepadanya.

Pendapat Maraghi ini juga dikuatkan oleh Ikrimah. Menurut Ikrimah, Lukman al-Hakim adalah seorang Nabi, orang yang bijaksana (al-hakim). Di dalam kitab Qatr al-Ghayts pun dikatakan bahwa di antara nabi-nabi dan Rasul yang telah disebutkan dalam Al-Qur'an itu sebenarnya masih banyak Nabi yang belum disebutkan namanya sehingga ada kemungkinan Luqman al-Hakim adalah salah satu di antara mereka.

2. Ibnu Abbas

Luqman al-Haim adalah seorang hamba sahaya dari Habasyiyah (Ethiophia), kemungkina besar dia itu adalah Aesopus, karena kata-kata hikma Aesopus mirip dengan kata-kata bijak Luqman. Aesopus adalah seorang hamba sahaya hitam pula yang menurut Winkler Prins Encyclopaedie ia hidup pada tahun 550-SM. Menurut Khalid al-Rab'I Luqman adalah seorang sahaya dan tukang kayu dari Habsi.

3. Hamka

Luqman al-Hakim adalah sosok pribadi yang senantiasa mendekatkan hatinya kepada Allah dan merenungkan keagungan alam ciptaan-Nya yang ada di sekelilingnya, sehingga dia mendapat kesan yang mendalam, demikian juga renungannya terhadap kehidupan ini. Sehingga pada akhirnya terbukalah baginya rahasia hidup (hikmah).

4. Imam Baidhawi

Menurut Imam Baidhawi dalam tafsirnyayang berjudul tafsir baidhawi menyebutkan bahwa Luqman adalah salah satu anak dari Azar, saudara sepupu Nabi Ayyub. Beliau hidup semasa Nabi Dawud dan pernah menjadi seorang mufti sebelum diutusnya Nabi Dawud sebagai Rasul. Lebih lanjut, Baidhawi 
menyebutka berdasarkan pendapat mayoritas ulama, luqman al-Hakim bukanlh seorang Nabi melainkan hanya seorang hakim.

Wahbah al-Zuhaili pun sependapat dengan Badhawi, beliau mengatakan dalam Tafsir al-Munir bahwa luqman al-Hakim adalah salah satu anak Azar, saudara sepupu Nabi Ayyub dan beliau berkulit hitam berasal dari Sudan Mesir, hidup sezaman dengan Nabi Dawud As kemudian beliau berguru kepadanya. $^{17}$

\section{c) Nilai-Nilai Pendidikan Karakter Dalam Surat Luqman Ayat 12-19}

a. Nilai Pendidikan Karakter pada Ayat ke-12

Pada Ayat ke 12 surat Luqman terdapat nilai karakter yaitu kata syukur yakni bersyukur kepada Allah, dan barang siapa yang bersyukur maka pada dasarnya ia bersuyukur untuk dirinya sendiri.

"Dan Sesungguhnya telah Kami berikan hikmat kepada Luqman, Yaitu: "Bersyukurlah kepada Allah. dan Barangsiapa yang bersyukur (kepada Allah), Maka Sesungguhnya ia bersyukur untuk dirinya sendiri; dan Barangsiapa yang tidak bersyukur, Maka Sesungguhnya Allah Maha Kaya lagi Maha Terpuji".

Dalam firman Allah ولقد اتينا لقمان الحكمة ان اشكر لله sesungguhnya Allah telah memberikan hikmah kepada Luqman agar ia selalu bersyukur dan meuji kepada-Nya atas apa yang telah diberikan kepadanya dri karunia-Nya, karena sesungguhnya hanya Dia-lah yang patut mendapat puji dan syukur itu.

Dan firman Allah ومن يشكر فإنما يشكر لنفسه tersebut sesungguhnya kembali kepada diri dirinya sendiri. Karena sesungguhnya Allah akan melimpahka kepadanya pahala yang berlimpah sebagai balasan dari-Nya atas rasa syukurnya dan dia kelak akan menyelamatkannya dari azab.

b. Nilai Pendidikan Karakter pada Ayat ke-13

"Dan (ingatlah) ketika Luqman berkata kepada anaknya, di waktu ia memberi pelajaran kepadanya: "Hai anakku, janganlah kamu mempersekutukan Allah, Sesungguhnya mempersekutukan (Allah) adalah benar-benar kezaliman yang besar".

${ }^{17}$ Wahbah al-Zuhali. Tafsir Al-Munir Juz XXI. Beirut: Darul Fikri, 1991, h. 91. 
Mengenai urgensi kisah Luqman ini, yang termuat dalam al-Qur'an merupakan petunjuk dan rahmat bagi orang yang berbuat baik.

Pada ayat ke-13 mengandung nilai pendidikan karakter yang bijaksana, yaitu wasiat Luqman terhadap anaknya menggambarkan idealitas keijaksanaan Luqman dalam bentuk perintah dan larangan yang memuat ajaran berbuat baik terhadap manusia, berbuat baik terhadap kedua orang tua dan ajaran mengikut jalan hidup orang mukmin.

c. Nilai Pendidikan Karakter pada Ayat Ke-14

"Dan Kami perintahkan kepada manusia (berbuat baik) kepada dua orang ibu- bapanya; ibunya telah mengandungnya dalam Keadaan lemah yang bertambah- tambah, dan menyapihnya dalam dua tahun. bersyukurlah kepadaku dan kepada dua orang ibu bapakmu, hanya kepada-Kulah kembalimu”.

Secara umu kaidah bersyukur menurut al-Qasimi memiliki lima kadah: Patuhnya orang yang bersyukur kepada yang disyukuri, mencintanya, mengakui nikmatnya, memuji nikmatnya dan tidak menggunakan nikmat itu untuk hal yang dibencinya.

Pada ayat ke-14 surat Luqman mengandung nilai pendidika karakter yakni amal shaleh, bersikap dan berperilau yang menunjukkan ketaatan dan berbuat baik kepada kedua orang tua dengan jalan bersyukur kepada Allah dan bersyukur kepada kedua orang tua dengan jalan berbuat baik kepada kedua orang tua yang di tunjukkan dengan sikap lemah lembut, menghindari kekerasan perilau dan tutur kata, ikut meringankan beban atau tanggungan orang tua.

d. Pendidikan Karakter pada Ayat ke-15

"Dan jika keduanya memaksamu untuk mempersekutukan dengan aku sesuatu yang tidak ada pengetahuanmu tentang itu, Maka janganlah kamu mengikuti keduanya, dan pergaulilah keduanya di dunia dengan baik, dan ikutilah jalan orang yang kembali kepada-Ku, kemudian hanya kepada-Kulah kembalimu, Maka Kuberitakan kepadamu apa yang telah kamu kerjakan. 
Berdasarkan ayat di atas dapat di pahami bahwa taat kepada Allah hukumnya wajib, demikian pula taat kepada kedua orang tua. Hanya saja menurut al-Maraghi taat kepada Allah itu mutlak dan taat kepada kedua orang tua hukumnya sangat dianjurkan. Jika kedua orang tua memerintahkan berbuat syirik, maka tidak wajib ditaati.

Pada ayat ke-15 surat Luqman mengandung nilai pendidikan karakter yaitu sikap hormat. Sikap hormat yaitu selalu berupaya untuk hormat kepada kedua orang tua bak dalam segala urusan dunia, dan bukan urusan agama. Pergaulan ini harus di lakukan dengan bak karena hal ini sangat dianjurkan dalam ajaran Islam.

e. Nilai Karakter pada Ayat ke-16

(Luqman berkata): "Hai anakku, Sesungguhnya jika ada (sesuatu perbuatan) seberat biji sawi, dan berada dalam batu atau di langit atau di dalam bumi, niscaya Allah akan mendatangkannya (membalasinya). Sesungguhnya Allah Maha Halus lagi Maha mengetahui.

Ayat ini menurut satu riwayat sebagaimana al-Baghdadi merupakan akhir wasiat yang di ucapkan Luqman, lalu wafat. Mayoritas mufassir mengatakan bahwa yang dimaksud dengan "sesuatu perbuatan" pada ayat di atas adalah perbuatan dosa. Perbuatan dosa sekecil apapun bentuknya dan sehebat apapun pelaku menyembunyikannya, Allah pasti mengetahuinya dan menampakkan ada hari kiamat.

Pada ayat ke-16 surat Luqman mengandung ila pendidikan karakter yatu ramah. Sikap ramah ditunjukkan dengan sikap dan perilau yang mneyenangkan terhadap anaknya baik tutur kata, maupun budi bahasa.

f. Nilai Karakter pada Ayat ke-17

Hai anakku, dirikanlah shalat dan suruhlah (manusia) mengerjakan yang baik dan cegahlah (mereka) dari perbuatan yang mungkar dan bersabarlah terhadap apa yang menimpa kamu. Sesungguhnya yang demikian itu Termasuk hal-hal yang diwajibkan (oleh Allah).

Berdasarka ayat di atas, penafsiran "dan bersabarlah atas apa yang menimpamu dari mar makruf nahi munkar" yakni bersabarlah atas sikap keras 


\section{Al-Tarbawi Al-Haditsah: Jurnal Pendidikan Islam}

Vol. 3, No. 2, Desember 2018

mereka jika kamu amar makruf nahi mungkar atas ujian yang menimpamu sehingga merisaukanmu, dari sini dapat diketahui bahwa mar makruf nahi munkar pasti rentan terhadap kekerasan dari masyarakat, sehingga menuntut sikap sabar.

Selain melakukan mar makruf nahi munkar. Nasihat Luqman juga menganjurkan untuk bersabar. Tidak jarang pelaksanaan amar makruf dan nahi munkar diikuti dengan ujian dan cobaan, maka dari itu hendaknya kita bersabar dalam menghadapinya.

Pada ayat ke-17 Surat Luqman mengandung nilai pendidikan karakter yaitu sabar. Bersabar atas apa yang menimpa dari amar makruf nahi munkar.

g. Nilai Karakter pada Ayat ke-18

"Dan janganlah kamu memalingkan mukamu dari manusia (karena sombong) dan janganlah kamu berjalan di muka bumi dengan angkuh. Sesungguhnya Allah tidak menyukai orang-orang yang sombong lagi membanggakan diri”.

Terdapat tiga dimensi tentang penafsiran ayat ini, pertama berarti larangan sombong, kedua kecondonngan pada manusia, ketiga berbicara dengan mencibirkan mulut.

Pada ayat ke-18 surat Lukman ini terdapat nilai pendidikan karakter yang rendah hati. Larangan sombong berarti hal ini menuntut manusia agar rendah hati, kalau berjalan tidak agkuh dan menampakkan kesenangan yang berlebihan karena Allah tidak menyuka orang yang berlebihan yaitu memamerkan kelebihannya.

h. Nilai Karakter pada Ayat ke-19

"Dan sederhanalah kamu dalam berjalan dan lunakkanlah suaramu. Sesungguhnya seburuk-buruk suara ialah suara keledai”.

Menurut al-Mawardi ayat ini memiliki lima pengertian. Pertama, berarti merendahkan diri. Kedua, ketika berjalan pandanglah ke jalan. Ketiga, bersegeralah dalam berjalan. Keempat, jangan bergegas dalam berjalan. Kelima, jangan sombong dalam berjalan. ${ }^{18}$

${ }^{18}$ At-Thabathabi. Al Mizan fi Tafsir al-Qur'an Juz 23. Libanon: Muassasat al-'Alamili al-Matba'ah, 1991, h. 224 
Pada ayat ke-19 surat Luqman mengandung nilai pendidika karakter yaitu pengendalian diri. Pengendalian diri dari yang dimaksud adalah menahan diri ketika berjalan maka sederhanakanlah janga tergesa-gesa, ketika berjala pandanglah ke jalan. Demikian pula dengan suara yaitu lunakkanlah suaramu tidak mesti dengan suara keras menyerupai khimar, karena keledai merupakan binatang yang paling jelak tubuh dan suaranya. Jadi dapat dipahami kalau berjalan itu memerlukan pengendalian diri, demikian juga ketika bersuara jagan terlalu keras seperti halnya suata keledai yang meringkik karena melihat syetan. Olehnya itu bagi tradisi Arab keledai digunakan untuk perumpamaan karena awal suaranya adalah teriakan dan akhirnya adalah rintihan.

Kandungan ayat 12-19 surat Luqman tersebut secara garis besar mengandung nilai-nilai pendidikan karakter sebagai berikut, syukur, bijaksana, amal shaleh, sikap hormat, ramah, sabar, rendah hati, dan pengendalian diri. Selain itu Luqman diberi hikmah oleh Allah. Dan sikap hikmag luqman ditunjukkan dengan menerapkan syukur, syukur luqman dilakukan dengan menasehati anaknya, Naishat dilakukan dengan penuh kasih sayang. Nasihat Luqman tersebut memuat materi akidah, syariah dan akhlak. ${ }^{19}$

\section{F. Relevansi Tri Pusat Pendidikan Ki Hajar Dewantara dengan Nilai-Nilai Pendidikan Karakter dalam Q.S Lukman: 12-19}

Untuk mengetahui relevansi Tripusat Pendidikan dengan nilai-nilai pendidikan karakter maka akan dijabarkan secara terperinci sebagai berikut:

\begin{tabular}{cc}
\multicolumn{2}{c}{ Pendidikan Karakter } \\
Pendidikan Karekter Melalui & Nilai Pendidikan Karakter Surah \\
Tripusat Pendidikan & Luqman ayat 12-19 \\
Lingkungan keluarga & Bersyukur kepada Allah \\
Lingkungan & Bijaksana \\
sekolah/perguruan & \\
Lingkungan Masyarakat & Amal Shaleh \\
\hline
\end{tabular}

${ }^{19}$ Muh. Arif, Nilai-Nilai Pendidikan Karakter dalam Al-Qur'an (Studi Q.S Luqman: 12-19),21-22. 
Al-Tarbawi Al-Haditsah: Jurnal Pendidikan Islam

Vol. 3, No. 2, Desember 2018

\begin{tabular}{cc} 
Ing Ngarsa Sung Tuladha & Sikap Hormat \\
Ing madya magun karsa & Ramah \\
Tutwuri Handayani & Sabar \\
& Rendah Hati \\
& Pengendalian diri \\
\hline
\end{tabular}

Dari tabel diatas dapat diperinci lagi seperti berikut:

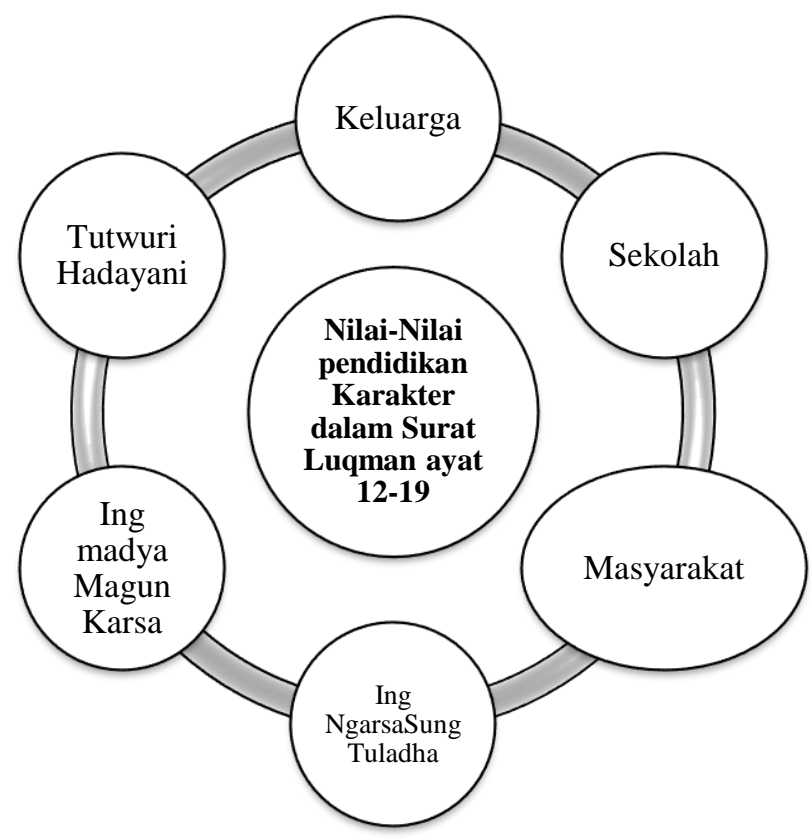

Dari tabel dan circle diatas dapat dipaparkan bahwa gagasan Tripusat Pendidikan dan sistem among milik Ki Hajar Dewantara dapat digunakan dalam pendidikan karakter terhadap peserta didik. Hal ini dikarenakan nila-nilai yang terkandung dalam surat Luqman ayat 12-19 dapat diajarkan melalu Tripusat Pendidikan maupun sistem among.

Dari lingkungan keluarga, khususnya ayah dan ibu dapat menanamkan nilai pada anak berupa rasa syukur kepada Allah, bijaksana, beramal shaleh, mengajarkan sikap hormat terhadap orang yang lebih tua, mengajarkan bagaimana cara bersifat ramah, bersabar, rendah hati serta pengendalian diri.

Kemudian di lingkungan sekolah atau perguruan, disini tugas guru untuk menekankan, menguatkan nilai-nilai karakter tersebut yang sebelumnya sudah 


\section{Al-Tarbawi Al-Haditsah: Jurnal Pendidikan Islam}

Vol. 3, No. 2, Desember 2018

diperoleh peserta didik dari lingkungan keluarganya. Dan memperbaiki nilai-nilai karakter yang dirasa tidak sesuai atau nilai karakter yang negatif.

Di Lingkungan masyarakat seorang anak atau peserta didik mampu mengaktualisasikan nilai-nilai karakter yang mereka peroleh dari lingkungan keluarga maupun sekolah. Sehingga nilai-nilai tersebut tidak hanya sekedar teori tanpa praktek. Dan dari lingkungan masyarakatlah, kita akan lebih jelas mengetahui pakah nilai-nilai karakter yang sudah diajarkan dan ditanamkan di lingkungan keluarga dan sekolah berhasil atau tidak.

Sedangkan dalam sistem among sendiri, guru harus bisa memberikan teladan yang nyata (Ing ngarsa sung tuladha) dari nilai-nilai karakter yang terdapat pada surat Luqman tersebut. Selain itu guru, pamong atau pendidik juga harus mampu berada ditengah-tengah sehingga mampu menumbuhka minat, hasrat dan kemampuan peserrta didik (Ing madya mangun karsa). Sehingga selain pintar intelektual mereka juga memiliki budi pekerti yang baaik dan luhur. Dan yang terakhir guru, pamong atau pendidik harus mampu memberikan perhatian, tanggung jawab, rasa kasih dan sayang kepada peserta didik (Tutwuri handayani), dengan memberikan nasihat dengan halus dan penuh pengertian sehingga peserta didik pun merasa mereka mampu memahami dan mengimplementasikan nilai-nilai karakter yang telah diajarkan tersebut.

\section{G. Kesimpulan}

Karakter sendiri berasa dari bahasa latin "Kharakter", "kharassein", "kharax", dalam bahasa Inggris yaitu character dan dalam bahasa indonesia disebut "karakter". Dalam bahasa yunani character dari charessein yang berarti membuat tajam, membuat dalam. Sedangka dalam kamus Poerwadarminta, karakter diartikan sebagai tabiat, watak, sifat-sifat kejiwaan, akhlak atau budi pekerti yang membedakan seseorang dengan yang lain. Nama dari jumlah seluruh ciri pribadi yang meliputi halhal seperti perilaku, kebiasaan, kesukaan, ketidaksukaan, kemapuan, kecenderungan, potensi, nilai-nilai, dan pola-pola pemikiran.

Honrnby dan Parnwell karakter adalah kualitas mental atau moral, kekuatan moral, nama atau reputasi Dan Kertajaya mendefinisikan karakter adalah ciri khas yang dimiliki oleh suatu benda atau individu. Ciri khas tersebut merupakan mesin pendorong bagaimana seorang bertindak, bersikap, berujar, dan merespons sesuatu 


\section{Al-Tarbawi Al-Haditsah: Jurnal Pendidikan Islam}

Vol. 3, No. 2, Desember 2018

Sedangka pendidikan karakter itu sendiri menurut Aneess dalam bukunya yaitu pendidikan untuk membentuk kepribadian seseorang melalui pendidikan budi pekerti, yang hasilnya terlihat dalam tindakan nyata seseorang, yaitu tingkah laku yang baik dan jujur, bertanggung jawab, menghormati hak orang lain, kerja keras, dan lain sebagainya. Hal ini pula dapat dikaitkan dengan takdib, yaitu pengenalan dan afirmasi atau aktualisasi hasil pengenalan.

Ki Hajar Dewantara tidak memandang perguruan atau sekolah sebagai lembaga satu-satunya yang memiliki orientasi mutla dalam proses pembentukan karakter anak. Justru dia memandang bahwa pendidikan sebagi suatu proses yang harus melibatkan unsur-unsur lain dari luar sekolah. Tiap-tiap pusat tersebut harus mengetahui kewajibannya masing-masing, atau kewajibannya sendiri-sendiri, dan mengakui hak pusat-pusat lainnya, yaitu lingkungan/alam keluarga, untuk mendidik budi pekerti dan laku sosial. Lingkungan/alam sekolah sebagai balai wiyata bertugas mencerdaskan cipta, rasa dan karsa secara seimbang. Dan lingkungan masyarakat/alam pemuda untuk melakukan penguasaan diri dalam pembentukan watak atau karakter.

Dan seorang pamong, guru atau pendidik harus mempunya sifat Ing ngarsa sing tuladha, Ing madya mangun karsa, dan tutwuri handayani yang termaktub dalam sistem among yang sampai sekarang pun masih di laksakana di perguruan taman siswa.

Pendidikan karakter melalui Tripusat pendidikan dan sistem among Ki Hajar Dewantara pun mempunyai relevansi terhadap nilai-nilai pendidikan karakter dalam surat Luqman ayat 12-19. Karena Nilai-nilai pendidikan karakter yang terdapat dalam surat Luqman tersebut dapat diajarkan melalui sistem among dan gagasan tripusat pendidikan, bahwa untuk mensukseskan suatu pendidika tiga pusat yaitu keluarga, sekolah, dan masyarakat tidak dapat dipisahkan satu sama lainnya.

\section{DAFTAR PUSTAKA}

Ainisyifa, Hilda. "Pendidikan Karakter dalam Perspektif Pendidikan Islam." Jurnal Pendidikan UNIGA (April 2014): 26-3. 
Al-Tarbawi Al-Haditsah: Jurnal Pendidikan Islam

Vol. 3, No. 2, Desember 2018

Al-Maraghi, Ahmad Musthafa. Tafsir al-MaraghiJuz 19. Beirut: Dar Ihya al Turasi al'Arabi, 1991.

Al-Zuhali, Wahbah. Tafsir al-Munir Juz XXI. Beirut: Darul Fikri, 1991.

Al-Tabathabi. Al-Mizan fi Tafsir al-Qur'an Juz 23. Libanon: Muassasat al-'Alamili alMatba'ah, 1991.

Anees, B.Q. Pendidikan Karakter Berbasis Al-Qur'an. Bandung: Simbiosa Rakatama, 2010.

Arif, Muh. "Nilai-Nilai Pendidikan Karakter Dalam Al-Qur'an (Studi Q.S. Lqman: 1219).” Jurnal Irfani (2015): 22-21.

Dewantara, Ki Hajar. Ki Hajar Dewantara dalam Majelis Luhur Persatuan Taman Siswa. 1997.

Haryanto. 2011. Pendidikan Karakter Menuut Ki Hajar Dewantara. Dalam Jurnal Cakrawala Pendidikan: Th xxx, spesial edidi Dies Natalis UNY.

Hasa al-Tusi, Abi Ja'far Muhammad.tt. Al-Tibyan al-Qur'an Juz 8. Dar Ihya' Turast Arabi.

Gunawan, Ki. Aktualisasi Konsep Pendidikan Ki Hajar Dewantara Dalam Sistem Pendidikan Nasional Indonesia di Gerbang XXI, dalam Ki Hajar Dewantara dala Pandangan Para Cantrik dan Mantriknya. Yogyakarta: MLPTS, 1989.

Majid, Abdul dan Dian Andayani. Pendidikan Karakter Perspektif Islam. Bandung: PT. Remaja Rosdakarya, 2012.

Mu'in, F. Pendidikan Karakter Kontruksi Teoritik dan Praktik.Yogyakarta: Ar-Ruzz, 2011.

Nuwadja dan Zuhaily, Wahba. Tafsir Ayat-Ayat Pendidikan. Bandung: MARJA, 2007.

Tafsir, Ahmad. Ilmu Pendidikan Islam. Bandung: Remaja Rosdakarya, 2013.

Quraish Syihab, Muhammad. Menyingkap Tabir Ilahi; Asma Al-Husna dalam Perspektif al-Qur'an. Jakarta: Lentera Hati, 1998. 